\title{
An investment development framework in Iran's seashores using TOPSIS and best-worst multi-criteria decision making methods
}

\author{
Kazem Askarifar ${ }^{a^{*}}$, Zohreh Motaffef $^{\mathrm{b}}$ and Saman Aazaami ${ }^{\mathrm{c}}$
}

\begin{abstract}
${ }^{a}$ Assistant Professor of Management, Economics, Management and Social Sciences School, Shiraz University, Shiraz, Iran
${ }^{b}$ M.Sc. of Management, Economics, Management and Social Sciences School, Shiraz University, Shiraz, Iran

${ }^{c}$ Student of Industrial Management, Economics, Management and Social Sciences School, Shiraz University, Shiraz, Iran

\section{H R O N I C L E}

\section{A B S T R A C T}

\begin{tabular}{l}
\hline Article history: \\
Received September 16, 2016 \\
Received in revised format: \\
October 22, 2016 \\
Accepted April15, 2017 \\
Available online \\
April 22, 2017 \\
\hline Keywords: \\
Investment \\
Infrastructure \\
Seashore \\
Mokran \\
TOPSIS \\
Best-worst multi-criteria decision \\
making method (BWM)
\end{tabular}

Mokran coasts have good potentials for development and investment, in terms of access to the high seas, geopolitical situation, especially, benefit from certain natural circumstances and history, but for various reasons, this area has no growth, commensurate with the potential. This study is conducted to evaluate investment opportunities in the region, to identify the necessary infrastructures and the promotion of entrepreneurial activities. The method identifies 22 investment opportunities through a comparative study and using best-worst multi-criteria decision method (BWM), and experts' opinion, the possibility of implementing them are ranked in Mokran. Then, the necessary public infrastructure requirements are ranked in eleven groups with TOPSIS. The results show that, private port sites, loading, warehouses, commercial centers and special areas of fisheries, provide good opportunities for investors, and infrastructure, security, transport, sustainable energy, and the single window government services are the priorities for planning in the public sector.

(C) 2018 Growing Science Ltd. All rights reserved.

\section{Introduction}

Today's investment is an important issue. In economic theory, investment is known as the engine of economic growth, and it is necessary to achieve the economic and social development, convenient and continuous economic growth. In economic terms, the net positive investment continually provides the necessary platform for the development and the establishment of the necessary technical investments. (Karami, 2008). Since, the economic structure of Iran heavily relies on oil exports, for the creation of sustainable development, as well as alternative sources of income it is necessary to use all other features and capabilities (Zangiabadi et al., 2006). One of these features is Iran's Ports and beaches, the Sea of Oman, the Persian Gulf, the Caspian Sea, and the Mokran port is one of them. Historically, Mokran port, is coastal territory in southeastern Iran and southwestern Pakistan, which is spread along the Gulf

* Corresponding author. Tel: +9871 36134462

E-mail address: kaskarifar@shirazu.ac.ir (K. Askarifar)

(C) 2018 Growing Science Ltd. All rights reserved. doi: $10.5267 /$ j.dsl.2017.4.004 
of Oman, from Raasolkooh, in West Jask, to Lasbela, in southwestern Balochistan province of Pakistan, and it was conquered by Cyrus the Great in $545 \mathrm{BC}$.

Mokran coast, have some strengths, such as free trade economic zone of Chabahar, perfect beaches, and coastal land right along the coast, great location, transit and shipping business. There are also beaches with the appropriate defense capabilities. Also, its proximity with the free international waters, over the southern border, neighboring Pakistan and Afghanistan, directly, and the Central Asian countries, indirectly, (through Turkmenistan) are the most important features of this area, which is an important way for these countries surrounded by land (except Pakistan) to the open sea. Unfortunately, infrastructure development and its substrates, there is a wide gap with the level of international standards and, therefore, this area has no growth commensurate with the potential.

Accordingly, the development of domestic and foreign investment in the region needs to identify opportunities. It is also important to locate the necessary infrastructures for the realization of these opportunities.

In this regard, this study is conducted to evaluate investment opportunities in the region, and to identify the necessary infrastructures, the promotion of entrepreneurial activities, based on the opportunity, and finally, the development model. Most of the studies executed in this field, have used the technique of SWOT, in order to identify opportunities and threats, and selecting appropriate strategies. In this study, we identify existing opportunities in various ports, through comparative study, and moderated the importance of this opportunity, the Mokran port, according to the experts, and identify their weights, using Best-Worst (Ghaffari et al., 2017) multi-criteria decision-making method. Next, we examin the effects of all the infrastructures for the realization of opportunities, and finally, we determin priorities of public sector investment in this area.

\subsection{Literature review}

After reviewing the studies performed, we did not observe any direct research, in recognizing the opportunities of the region, and the necessary infrastructure to realize those opportunities. However, there are a number of internal and external investigations, which were carried out in coastal areas, and with the approach of tourism development or investment, or merely to identify opportunities and threats, and to provide appropriate strategies.

Mamipour et al. (2014), in their study, n Anzali Free Zone, and prioritized investment opportunities with the of analytical hierarchy process (AHP) (Saaty, 1994). Based on the findings of their research, operating facilities, is the number one cause of policy followed by the economic factor, operating rules, regulations, management agent, support element and the location. In other research, Rezai et al. (2013) examined the strengths, weaknesses, opportunities and threats in development of ecotourism in the island, and finally, offered some suggestions. The findings showed that, natural attractions and special ecosystems, historic buildings and cultural sites, and believe executives nature, are the strengths of the island, and inappropriate ads, climatic conditions difficult, in half a year, and inappropriate marketing, to attract domestic and foreign tourists are weaknesses. Also, jobs to help the tourism industry, and foreign exchange earnings for the country, are opportunities outside the region, and inadequate funding and a national reputation for research and tourism development, lack of infrastructure, quality nozzle tourism centers, destruction of historical and natural resources area are external threats to the region. In this regard, researchers offered four key strategies including implementation of studies of economic and technical justification with an emphasis on natural attractions and cultural, taking advantage of the facilities of the development of the island, in order to teach and informing residents and tourists, educating residents and tourists in the region, about the importance of natural ecosystems, and the value of historical and natural monuments and works of the region, and the use of accommodation and service of the development of Qeshm to serve primarily to tourism in the short term.

Dadvarkhani et al. (2012) analyzed the strengths, weaknesses, opportunities and threats to the lake, the technique SWOT, to develop tourism in the area. According to the results, it was found that, pristine 
habitats, and protected and rare plant and animal species, and property Mud, of the Lake, are the most important strengths of the lake. Also, hypothyroidism authorities, the restoration of tourism projects are the disadvantages of the region. The opportunities outside, affecting tourism in the lake, up the lake in the Ramsar Convention, is the most important component, and the lack of actual and constant position of the Lake, in the allocation of public funds and the country's development, and unauthorized use predators from ecosystems of the lake, are the most important threats to tourism in the lake.

Ebrahimzadeh and Aghasizadeh (2009), in their study looked at factors affecting tourism development in the coastal zone of Chabahar using SWOT. The explained that the city had the potential to become a good tourism area, but multiple decision makers and management problems, lack of infrastructure, and lack of advertising, were major obstacles. However, there are areas of employment, foreign exchange earnings, and investment in infrastructure, the opportunities and historical sites, sport recreation, sandy beaches, and natural charm, the development and modification of management institutions, strengthen publicity and intellectual interaction among authorities free zone, are the strengths and catchy. Also related to tourism and public organizations, and the development of ecotourism, are the most important approaches to develop tourism in the area.

Tian et al. (2013), in their study, evaluated the stability of wind power projects in China Yancheng beach using AHP. The findings showed that wind energy projects had poor stability. Also, evidence suggests that birds were killed due to collisions with wind turbines. On the other hand, the turbines produced annoying sound, and made the landscape ugly. Therefore, some measures must be taken in the design and manufacture of turbines. For example, new models made of tubular steel tower used in the design phase, to prevent the death of the birds.

\section{Material and methods}

The research paradigm, this study, is exploratory mixed, and it is library and field, in terms of purpose, and in terms of monitoring and control of temperature. In terms of data collection, descriptive-case study, and based on the time horizon is associated with the second half of 2016. The study population for this study, includes the investment experts in ports and free zones. In this way, the researchers used people, who had rich experience of the subject (investment in ports), and be expressed, and willing to participate in the research. At these stages, the researchers identified the key people informed, through the initial study and inquired about the matter, then, sampling was carried out using Snowball method, the number of samples in the study were 26 experts. In this study, a content analysis has been used to collect and infrastructure investment opportunities in the ports. Accordingly, the concepts and code means were extracted by repeated study and review of the resources available, and were placed on the list of opportunities and infrastructure. Also, in this study, the validity of the results were confirmed, using the techniques of control members, using different researchers in collecting and analyzing data, and self-control researcher. The results of the study have been confirmed, with the help of review analysis by the research team and other researchers, using detailed descriptions of the transfer, and research conditions in detail.

In the study, five ports were chosen by the researchers, by examining the content of different databases ports, based on structural similarity of access and ports, and information about opportunities, and infrastructure investment and entrepreneurship were extracted. Then, the importance and priority opportunity to Mokran port have been found, according to the experts, using Best-Worst Multi-criteria Decision Making Method (BWM). Then, to determine the priority of the identified infrastructures, to invest in the development Mokran port, weighted opportunities were considered as a benchmark, and the impact of any infrastructure, on the realization of various opportunities, was determined using experts' opinions and finally, they were prioritized, by the TOPSIS (Hwang \& Yoon, 1981) technique.

\subsection{Investment opportunities}

In the first step of the study, using previous studies, opportunities of investment in the five ports of Asia and the Pacific, were identified. List of identified opportunities are given in Table 1. 


\section{Table 1}

Investment opportunities 5 Port in Asia and the Pacific

\begin{tabular}{|c|c|c|c|c|c|c|}
\hline & Opportunities & $\begin{array}{l}\text { Karachi } \\
\text { Pakistan }\end{array}$ & $\begin{array}{c}\text { Duqm } \\
\text { Omman }\end{array}$ & Kuwait & $\begin{array}{c}\text { Victor } \\
\text { Australia }\end{array}$ & $\begin{array}{c}\text { Fremantle } \\
\text { Australia }\end{array}$ \\
\hline 1 & Private Ports & $\checkmark$ & $\checkmark$ & $\checkmark$ & $\checkmark$ & $\checkmark$ \\
\hline 2 & University Complexes & $\checkmark$ & & $\checkmark$ & $\checkmark$ & $\checkmark$ \\
\hline 3 & Water Parks & & & $\checkmark$ & $\checkmark$ & $\checkmark$ \\
\hline 4 & Hotel/Motel & $\checkmark$ & $\checkmark$ & $\checkmark$ & $\checkmark$ & $\checkmark$ \\
\hline 5 & Goods Warehouses & $\checkmark$ & $\checkmark$ & $\checkmark$ & $\checkmark$ & $\checkmark$ \\
\hline 6 & Oil Reservoirs & & & $\checkmark$ & & \\
\hline 7 & Petrochemical Products Packaging Plants & & & $\checkmark$ & & \\
\hline 8 & Eco Tourism & & & $\checkmark$ & & $\checkmark$ \\
\hline 9 & Shopping Center & $\checkmark$ & $\checkmark$ & $\checkmark$ & & $\checkmark$ \\
\hline 10 & Maritime Museum & & & $\checkmark$ & & $\checkmark$ \\
\hline 11 & Dockyard & & & & & \\
\hline 12 & Marine Loading Terminal & $\checkmark$ & $\checkmark$ & $\checkmark$ & $\checkmark$ & $\checkmark$ \\
\hline 13 & Amusement park & $\checkmark$ & $\checkmark$ & & $\checkmark$ & $\checkmark$ \\
\hline 14 & Water Sports Clubs & & & & $\checkmark$ & $\checkmark$ \\
\hline 15 & Industrial Zones & $\checkmark$ & $\checkmark$ & $\checkmark$ & $\checkmark$ & $\checkmark$ \\
\hline 16 & Green House Garden & & & & $\checkmark$ & $\checkmark$ \\
\hline 17 & Cold Storage Warehouse & $\checkmark$ & & $\checkmark$ & $\checkmark$ & \\
\hline 18 & Real State/Residential Zone & & $\checkmark$ & $\checkmark$ & $\checkmark$ & $\checkmark$ \\
\hline 19 & Wind Power Plants & $\checkmark$ & & $\checkmark$ & & \\
\hline 20 & livestock slaughter & $\checkmark$ & & & & \\
\hline 21 & Fishery Zones & $\checkmark$ & $\checkmark$ & & & $\checkmark$ \\
\hline 22 & Health and Medicare Towns & $\checkmark$ & & $\checkmark$ & & \\
\hline
\end{tabular}

\subsection{Weight of the importance of opportunities}

To find the optimal weights for choices $\left(w_{j}^{*}\right)$, for all (j)s, maximum of $\left|\frac{w_{B}}{w_{j}}-a_{B j}\right|$ and $\left|\frac{w_{j}}{w_{W}}-a_{j W}\right|$ must become minimum and non-negative values of $w_{j}$ are equal to 1 (Rezaei, 2015). Simplified mathematical programming models is as follows.

$\min \zeta$

s.t.

$\left|\frac{w_{B}}{w_{j}}-a_{B j}\right| \leq \zeta \quad$ for $j=1,2, \ldots, 22$

$\left|\frac{w_{j}}{w_{W}}-a_{j W}\right| \leq \zeta \quad$ for $j=1,2, \ldots, 22$

$\sum_{j} w_{j}=1$

$w_{j} \geq 0 \quad$ for $j=1,2, \ldots, 22$

\subsection{Infrastructure investment}

Identification of the infrastructure, along with the proportion of infrastructure investment opportunities, is the next step for the development of model. Table 2 shows the existing infrastructure in the five ports. 
Table 2

Infrastructure of investment, the fifth port of Asia and the Pacific

\begin{tabular}{|c|c|c|}
\hline$A b b$. & Infrastructure & Examples* \\
\hline \multirow{2}{*}{$\mathrm{g} 1$} & \multirow{2}{*}{ Communication Services } & Internet Services \\
\hline & & Telecommunication Systems \\
\hline \multirow{3}{*}{ g2 } & \multirow{3}{*}{ Cultural Infrastructure } & Library \\
\hline & & Mosque \\
\hline & & Church \\
\hline \multirow{4}{*}{ g3 } & \multirow{4}{*}{ Educational Services } & Further Education \\
\hline & & Pre-School \\
\hline & & Primary School \\
\hline & & Secondary School \\
\hline \multirow{3}{*}{$\mathrm{g} 4$} & \multirow{3}{*}{ Energy Supplement } & Gas \& Gasoline supply \\
\hline & & High Voltage Electricity Distribution Network \\
\hline & & Stable Electricity Power \\
\hline \multirow{3}{*}{ g5 } & \multirow{3}{*}{ Environmental Services } & Drainage and Storm water Systems \\
\hline & & Effluent Disposal Systems \\
\hline & & Waste Management Services \\
\hline \multirow{2}{*}{ g6 } & \multirow{2}{*}{ Financial Services } & Bank \\
\hline & & Discount Department Store \\
\hline \multirow{3}{*}{ g7 } & \multirow{3}{*}{ Heath Care Services } & Community Health Centre \\
\hline & & Day Care Centre \\
\hline & & Hospital \\
\hline \multirow{3}{*}{ g8 } & \multirow{3}{*}{ Official Services } & Civic Centre \\
\hline & & Consulting Room \\
\hline & & Custom offices \\
\hline \multirow[b]{2}{*}{ g9 } & \multirow{2}{*}{ Residential } & Caravan and Tourist Parks \\
\hline & & Child Minding/Child Care Center \\
\hline \multirow{3}{*}{$\mathrm{g} 10$} & \multirow{3}{*}{ Security Services } & Fire Fighting Station \\
\hline & & Police Station \\
\hline & & Court, Judicial and legal Services \\
\hline \multirow{5}{*}{ g11 } & \multirow{5}{*}{ Transportation } & Bus Network \\
\hline & & Centralized Parking \\
\hline & & Rail network \\
\hline & & Road Parking \\
\hline & & Airport \\
\hline
\end{tabular}

Among the identified infrastructure, which should be provided in the public sector by the district administration, we have divided them in eleven groups as shown in Table 2.

\subsection{TOPSIS}

TOPSIS is one of the ways of prioritizing choices decided, in multi attribute decision making (MADM), where $m$ alternatives are evaluated based on $n$ indexes. The main ideas of this technique, is to compare the decided choices, with positive and negative ideal, and to determine the distance of each of the choices, in terms of both positive and negative ideals, and in the end, we choose the choice that is closest to the positive ideal, and far from ideal. The steps of this method are as follows:

First, decision matrix become without scale, using Euclidean norm by Eq. (1)

$$
n_{i j}=\frac{r_{i j}}{\sqrt{\sum_{\mathrm{i}=1}^{\mathrm{m}} r_{i j}^{2}}}
$$

Then, weights of each index, are multiplied according to Eq. (2), and the weighted normalized matrix is obtained.

$$
\mathrm{v}=\mathrm{Nd} * \mathrm{~W}
$$

After that, the positive and negative ideal are achieved with the use of Eq. (3) and Eq. (4):

$$
\begin{aligned}
& A^{+}=\langle(\max v i j \mid j \in J),(\min v i j \mid j \in K), j=1,2, \ldots, m\rangle \\
& A^{-}=\langle(\min v i j \mid j \in J),(\max v i j \mid j \in K), j=1,2, \ldots, m\rangle
\end{aligned}
$$

After that, the difference of choices from positive and negative ideals are achieved using the Eq. (5) and Eq. (6): 


$$
\begin{aligned}
& \mathrm{di}^{+}=\sqrt{\left\{\sum_{j=1}^{n}\left(v i j-v i j^{+}\right)^{2}\right\}}, \\
& \mathrm{di}^{-}=\sqrt{\left\{\sum_{j=1}^{n}\left(v i j-v i j^{-}\right)^{2}\right\}},
\end{aligned}
$$

and finally, the criteria of the choice $i$ and the ideal solution proximity are calculated using Eq. (7):

$$
\mathrm{CLi}^{+}=\frac{\mathrm{di}^{-}}{\mathrm{di}^{-}+\mathrm{di}^{+}}
$$

Choices priorities are based on the descending order. (Asgharpour, 2013)

\section{Results}

BWM method is used, in order to adapt the potential of Mokran port, the identified opportunities. In this way, according to the experts, the best choice for Mokran port is Private Ports, and the worst choice, is Health and Medicare Towns.

\section{Table 3}

Average values of the experts in the field of identified opportunities to the Mokran port

\begin{tabular}{clcc}
\hline & & Best: & Worst: \\
& & Private Ports & Health and Medicare Towns \\
$j$ & Opportunities & $a_{B j}$ & $a_{j W}$ \\
\hline $\mathrm{j}_{1}$ & Amusement Park & 6.1 & 3.4 \\
$\mathrm{j}_{2}$ & Cold Storage Warehouse & 5.4 & 6.6 \\
$\mathrm{j}_{3}$ & Dockyard & 2.4 & 7.4 \\
$\mathrm{j}_{4}$ & Eco Tourism & 3.5 & 2.9 \\
$\mathrm{j}_{5}$ & Fishery Zones & 2.7 & 9.3 \\
$\mathrm{j}_{6}$ & Goods Warehouses & 1.8 & 9.4 \\
$\mathrm{j}_{7}$ & Green House Garden & 6.4 & 1.9 \\
$\mathrm{j}_{8}$ & Health and Medicare Towns & 7.1 & 1.0 \\
$\mathrm{j}_{9}$ & Hotel/Motel & 6.6 & 7.1 \\
$\mathrm{j}_{10}$ & Industrial Zones & 3.7 & 5.4 \\
$\mathrm{j}_{11}$ & Livestock Slaughter & 5.3 & 6.4 \\
$\mathrm{j}_{12}$ & Marine Loading Terminal & 1.7 & 7.6 \\
$\mathrm{j}_{13}$ & Maritime Museum & 6.5 & 2 \\
$\mathrm{j}_{14}$ & Oil Reservoirs & 5.3 & 7.6 \\
$\mathrm{j}_{15}$ & petrochemical Products Packaging Plants & 5.7 & 7.0 \\
$\mathrm{j}_{16}$ & Private Ports & 1.0 & 8.4 \\
$\mathrm{j}_{17}$ & Real State/Residential Zone & 6.4 & 2.4 \\
$\mathrm{j}_{18}$ & Shopping Centers & 3.5 & 8.5 \\
$\mathrm{j}_{19}$ & University Complexes & 6.7 & 4.2 \\
$\mathrm{j}_{20}$ & Water Parks & 8.4 & 5.5 \\
$\mathrm{j}_{21}$ & Water Sports Clubs & 7.0 & 3.7 \\
$\mathrm{j}_{22}$ & Wind Power Plants & 5.2 & 6.6 \\
\hline Source: & research findings & & \\
\hline
\end{tabular}

Source: research findings

Accordingly, the preferred best choice is compared with other choices $\left(a_{B j}\right)$ by experts and the superiority of the worst choices $\left(a_{j W}\right)$, initialize a scale from 1 to 10 . The average of the obtained 
values, are given in Table 3. Table 3 shows the importance of different opportunities using $a_{B j}$ and $a_{j W}$.

$\min \zeta$

subject to

$\left|\frac{w_{B}}{w_{1}}-6.1\right| \leq \zeta, \quad\left|\frac{w_{B}}{w_{2}}-5.4\right| \leq \zeta$,

$\left|\frac{w_{B}}{w_{22}}-5.2\right| \leq \zeta, \quad\left|\frac{w_{1}}{w_{W}}-3.4\right| \leq \zeta, \quad\left|\frac{w_{2}}{w_{W}}-6.6\right| \leq \zeta$

$\left|\frac{w_{22}}{w_{W}}-6.6\right| \leq \zeta$

$w_{j}+w_{2}+\ldots+w_{22}=1$

$w_{1}, w_{2}, \ldots, w_{22} \geq 0$

The resulted model given in Eq. (8) is solved using MATLAB optimization toolbox, and weight of each investment opportunity, in the Mokran coast, were determined. Fig. 1 shows the weights of investment opportunities in Mokran coast. Table 4 also shows other information.

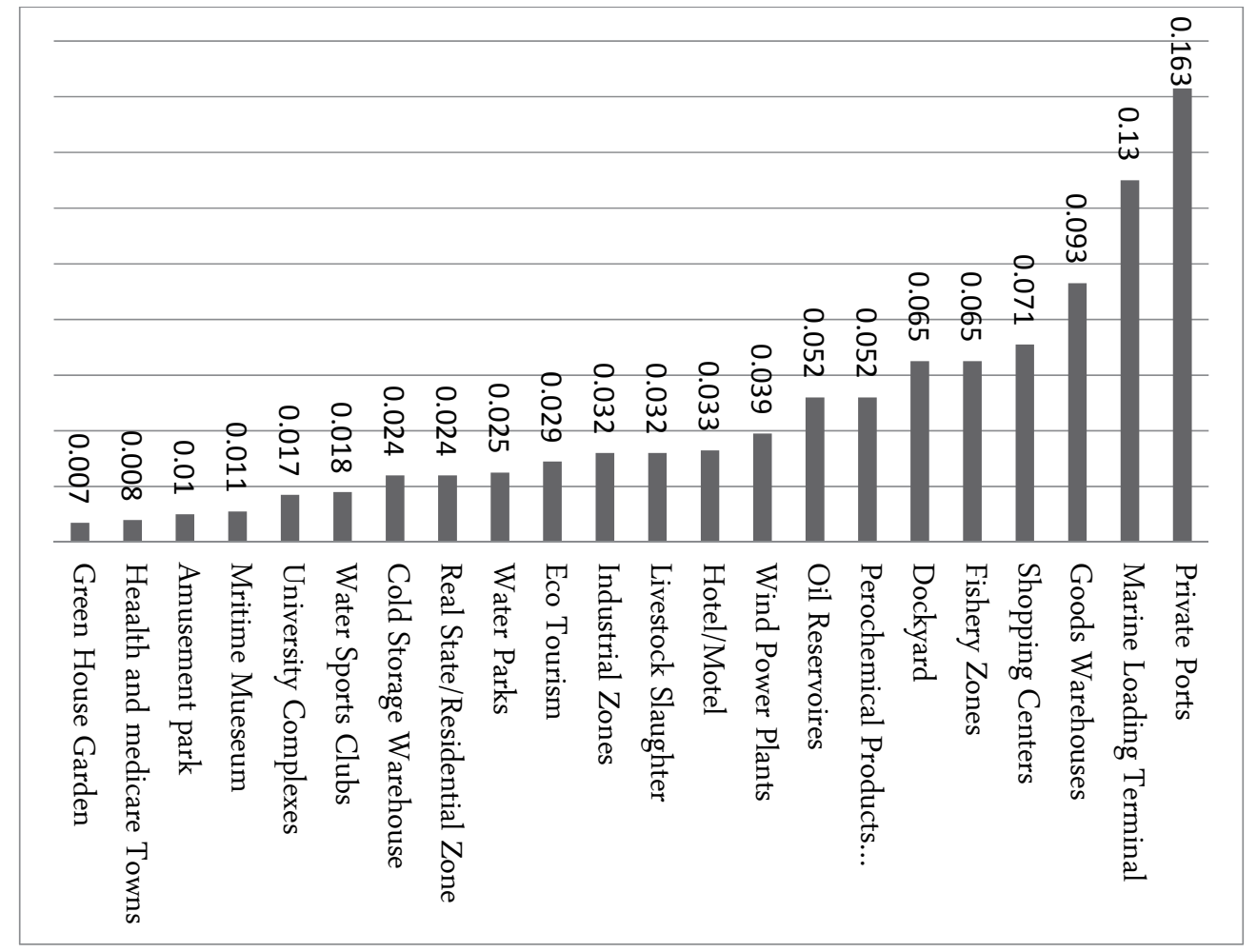

Fig. 1. The weights of investment opportunities for Mokran coast 
Table 4

Mean of expert opinion for the impact of infrastructures investment opportunities in in realization of investment opportunities

\begin{tabular}{|c|c|c|c|c|c|c|c|c|c|c|c|c|}
\hline & & $j_{1}$ & $j_{2}$ & $j_{3}$ & $j_{4}$ & $j_{5}$ & $j_{6}$ & $j_{7}$ & $j_{8}$ & $j_{9}$ & $j_{10}$ & $j_{11}$ \\
\hline$g_{1}$ & Communication Services & 3.2 & 4.1 & 4.3 & 7.3 & 3.2 & 4.2 & 3.3 & 7.8 & 8.9 & 5.7 & 4.2 \\
\hline$g_{2}$ & Cultural Infrastructure & 6.1 & 4.2 & 4.1 & 6.8 & 5.3 & 4.9 & 6.0 & 8.3 & 8.7 & 5.3 & 3.6 \\
\hline$g_{3}$ & Educational Services & 2.6 & 1.6 & 4.4 & 3.4 & 5.3 & 1.7 & 2.9 & 3.0 & 4.1 & 5.3 & 4.0 \\
\hline$g_{4}$ & Energy Supplement & 6.4 & 9.1 & 8.7 & 5.6 & 7.1 & 7.1 & 8.1 & 9.2 & 8.9 & 8.9 & 7.8 \\
\hline$g_{5}$ & Environmental Services & 8.0 & 9.2 & 6.1 & 9.9 & 8.6 & 5.6 & 4.3 & 8.2 & 9.3 & 7.4 & 9.2 \\
\hline$g_{6}$ & Financial Services & 7.2 & 7.9 & 6.4 & 6.7 & 5.7 & 5.6 & 5.0 & 7.4 & 8.0 & 7.3 & 6.0 \\
\hline$g_{7}$ & Heath Care Services & 8.3 & 7.4 & 6.6 & 9.2 & 7.9 & 5.6 & 5.0 & 6.6 & 8.2 & 7.0 & 6.7 \\
\hline$g_{8}$ & Official Services & 5.2 & 6.9 & 7.6 & 6.7 & 7.3 & 6.9 & 6.2 & 7.6 & 8.1 & 8.1 & 6.6 \\
\hline$g_{9}$ & Residential & 6.4 & 5.4 & 6.7 & 7.8 & 4.8 & 6.2 & 5.2 & 8.6 & 9.4 & 6.7 & 4.7 \\
\hline & Security Services & 8.1 & 9.1 & 8.4 & 9.0 & 7.4 & 7.1 & 6.4 & 7.7 & 9.3 & 8.2 & 6.9 \\
\hline & Transportation & 7.9 & 8.1 & 6.4 & 8.2 & 6.6 & 7.8 & 5.7 & 8.2 & 9.2 & 8.4 & 7.0 \\
\hline
\end{tabular}

\section{Table 4}

Mean of expert opinion for the impact of infrastructures investment opportunities in in realization of investment opportunities (Continued)

\begin{tabular}{|c|c|c|c|c|c|c|c|c|c|c|c|c|}
\hline & & $j_{12}$ & $j_{13}$ & $j_{14}$ & $j_{15}$ & $j_{16}$ & $j_{17}$ & $j_{18}$ & $j_{19}$ & $j_{20}$ & $j_{21}$ & $j_{22}$ \\
\hline$g_{1}$ & Communication Services & 5.7 & 7.1 & 1.6 & 3.0 & 4.3 & 7.3 & 8.1 & 8.8 & 4.2 & 6.0 & 1.9 \\
\hline$g_{2}$ & Cultural Infrastructure & 5.9 & 6.9 & 2.1 & 2.0 & 6.3 & 7.9 & 9.0 & 8.1 & 7.9 & 8.9 & 2.4 \\
\hline$g_{3}$ & Educational Services & 3.1 & 1.9 & 0.8 & 3.6 & 3.1 & 9.0 & 4.4 & 9.7 & 2.9 & 4.1 & 1.9 \\
\hline$g_{4}$ & Energy Supplement & 8.8 & 6.2 & 3.8 & 6.0 & 7.7 & 6.0 & 7.4 & 6.9 & 7.4 & 7.1 & 8.2 \\
\hline$g_{5}$ & Environmental Services & 6.3 & 5.7 & 4.8 & 5.7 & 5.6 & 8.1 & 7.6 & 7.3 & 7.0 & 6.4 & 4.8 \\
\hline$g_{6}$ & Financial Services & 7.7 & 6.6 & 4.6 & 6.4 & 7.0 & 7.6 & 9.2 & 8.2 & 7.1 & 7.3 & 7.1 \\
\hline$g_{7}$ & Heath Care Services & 6.8 & 8.1 & 4.6 & 5.9 & 6.8 & 9.2 & 8.1 & 8.1 & 6.6 & 7.8 & 5.2 \\
\hline$g_{8}$ & Official Services & 6.8 & 6.3 & 5.4 & 5.9 & 8.4 & 7.8 & 6.0 & 5.6 & 7.4 & 7.2 & 6.2 \\
\hline$g_{9}$ & Residential & 6.3 & 7.7 & 2.6 & 5.2 & 6.1 & 7.9 & 9.3 & 8.4 & 8.1 & 7.7 & 2.3 \\
\hline$G_{1}$ & Security Services & 8.4 & 8.2 & 7.0 & 7.2 & 8.3 & 8.8 & 9.1 & 8.4 & 8.0 & 8.8 & 8.4 \\
\hline$g_{11}$ & Transportation & 7.6 & 7.6 & 4.7 & 7.8 & 8.6 & 7.6 & 9.3 & 7.6 & 8.1 & 8.3 & 8.2 \\
\hline
\end{tabular}

Then, the importance of each of the eleven infrastructures were found using TOPSIS. Table 3-5 show the weights. Table 5 shows the priorities of the infrastructrures for investment.

Table 5

Results of the priorities of the infrastructure for investment

\begin{tabular}{lllll}
\hline & & $S_{g}^{+}\left(\times 10^{-6}\right)$ & $S_{g}^{+}\left(\times 10^{-6}\right)$ & Weight \\
\hline$g_{1}$ & Communication Services & 2946 & 629 & 0.18 \\
$g_{2}$ & Cultural Infrastructure & 1926 & 1351 & 0.41 \\
$g_{3}$ & Educational Services & 5093 & 76 & 0.01 \\
$g_{4}$ & Energy Supplement & 313 & 3854 & 0.92 \\
$g_{5}$ & Environmental Services & 1042 & 2024 & 0.66 \\
$g_{6}$ & Financial Services & 566 & 2712 & 0.83 \\
$g_{7}$ & Heath Care Services & 650 & 2417 & 0.79 \\
$g_{8}$ & Official Services & 392 & 3453 & 0.90 \\
$g_{9}$ & Residential & 1322 & 1789 & 0.58 \\
$G_{1}$ & Security Services & 54 & 4661 & 0.99 \\
$g_{11}$ & Transportation & 228 & 4275 & 0.95 \\
\hline
\end{tabular}




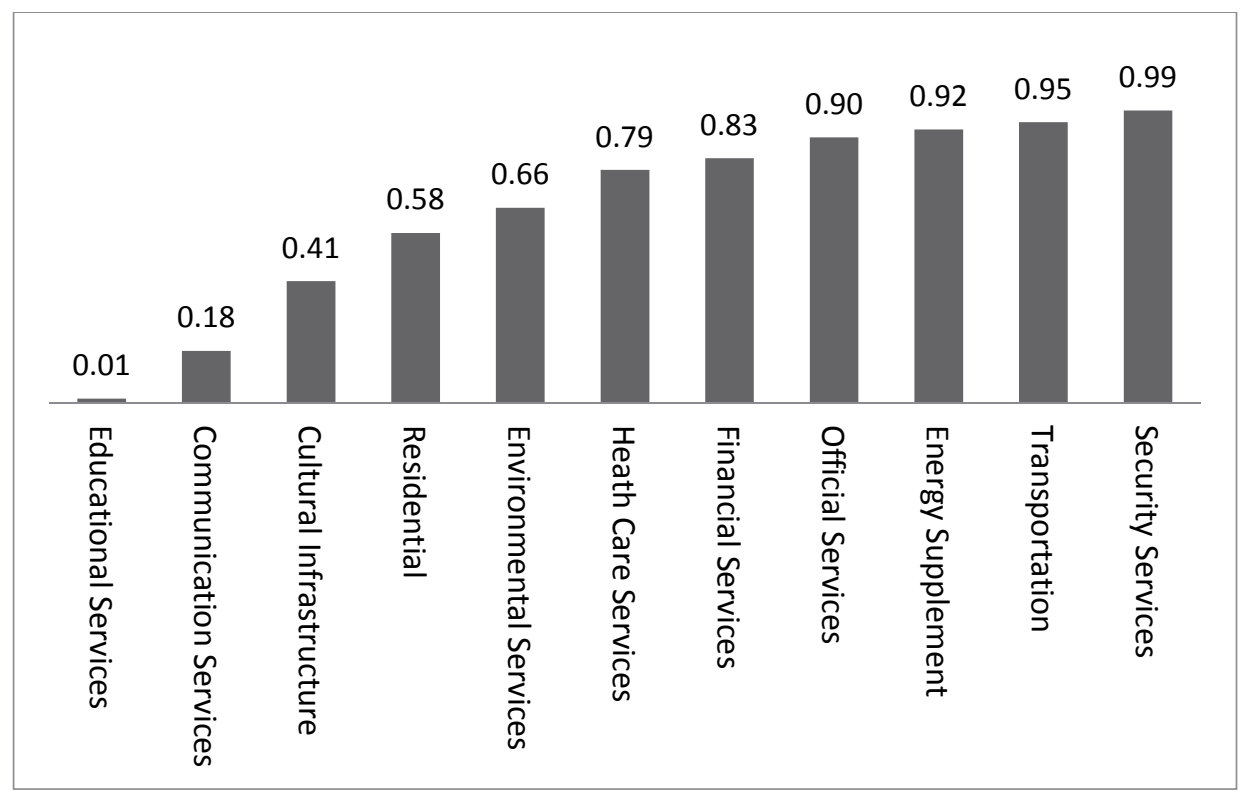

Fig. 2. The final results of ranking different alternatives

\section{Discussion}

As mentioned, Mokran coast, due to its special geographical location, has numerous opportunities and capabilities, which could attract adequate capital, and lead to a boom business in this area. Unfortunately, this has been neglected due to lack of proper infrastructure investments. The importance of this research is in identifying opportunities of the region, and infrastructures commensurate with the opportunities for investors in this strategic area, in this regard, the opportunities available in 5 coasts of Asia and the Pacific were identified, and their importance in the Mokran coast, was determined by survey experts, and best-worst MCDM method. Then, the existing infrastructure on the coast, were reviewed, and their impacts on the realization of any of the time-shore Mokran became clear, with a survey of experts, and based on the weight of importance, opportunities, priorities were determined using TOPSIS.

\section{Conclusion}

According to results of this research, Table 4 shows that, ports and private terminals loading and storage of goods, are the best choices for investment. In addition, shopping centers, and areas of fisheries are other suitable investment opportunities in this port. According to experts, some businesses, such as gardens, greenhouses, health centers, and amusement parks, are the jobs that are less favorable for the investments in Mokran. On the other hand, as shown in Table 5, to develop the Mokran coast, from an economic perspective, and to realize the opportunities that have higher priorities, security infrastructure, transport, and energy should be the priorities of the district administration. Then, administrative, and monetary and banking services are other infrastructure priorities, which have significant impacts for the regional development.

\section{References}

Asgharpour, M. (2013). Multi Creteria Decision Making, Tehran: Tehran University Publishers.

Dadvarkhani, F., Ghasemi, Y., \& Shokravi, N. (2012). Stretegic analysis for tourisim development based on ecological potential of Oroumieh lake using SWOT. Journal of Wetland Ecobiology, 12, 81-93.

Department of Planning, Transport and Infrastructure of South Australia Government (2016). Development Plan of Victor Harbor 2016, Available on www.sa.gov.au/developmentplans, retrieved on 2016.11.05. 
Ebrahimzadeh, E., \& Aghazadeh, A. (2009). Analysis of impacts on tourism development in the coastal zone of Chabahar, using SWOT strategic model. Urban and Regional Studies and Research, 1, 107128.

Fremantle Ports (2016). Fremantle Ports 2016 Annual Report, Available at http://www.fremantleports.com.au/News/Publications/AnnualReport/Documen s/2016\%20Annual\%20Report\%20-\%20Full\%20Report.pdf, retrieved on 2016.10.15.

Ghaffari, S., Arab, A., Nafari, J., \& Manteghi, M. (2017). Investigation and evaluation of key success factors in technological innovation development based on BWM. Decision Science Letters, 6(3), 295-306.

Hofherr, J., Natale, F., \& Trujillo, P. (2015). Is lack of space a limiting factor for the development of aquaculture in EU coastal areas? Ocean \& Coastal Management, 116, 27-36.

Hwang, C. L., \& Yoon, K. (1981). Multiple criteria decision making. Lecture Notes in Economics and Mathematical Systems, 186.

Karami, A. (2008). Pathology in Iran's capital market and the challenges ahead. Tadbir e Eghtesad Research Institute, 16.

Karachi Metropolitan Corporation (2016). Karachi Economic Hub of South Asia, Available on http://www.kmc.gos.pk/Contents.aspx?id=46, 2017.10.10.

Kuwait Direct Investment Promotion Authority (2016). Investing in Kuwait: A guide for Investment Opportunities in Kuwait, KDIPA, Available on http://kdipa.gov.kw/wp-content/uploads/KDIPAInvestment-Guide-2016.pdf, retrieved on 2016.10.15.

Mamipour, S., Besharati, Z., \& Behboodi, D. (2014). Identifying and Prioritizing investment agents, in Anzali Free Zone. Economy and Regional Development, 20 (7), 133-165.

Port of Doqm Company (2016). Investment Opportunities, Available on https://www.portduqm.com/Business/Investment-Opportunities.html, retrieved on 2016.10.14.

Rezai, S., Josie, A., \& Pirasteh, A. (2013). Providing Strategic Management Plan for the development of ecotourism in the island, using SWOT. Environmental Science and Technology, 15(1), 91-109.

Rezaei, J. (2015). Best-worst multi-criteria decision-making method. Omega, 5, 49-57.

Saaty, T. L. (1994). How to make a decision: the analytic hierarchy process. Interfaces, 24(6), 19-43.

Tian, W., Bai, J., Sun, H., \& Zhao, Y. (2013). Application of the analytic hierarchy process to a sustainability assessment of coastal beach exploitation: a case study of the wind power projects on the coastal beaches of Yancheng, China. Environmental management, 115, 251-256.

Zangiabadi, A., Mohammadi, J., \& Zirakbash, D. (2006). Analysis of Domestic Tourism in Isfahan. Geography and Development, 8, 131-156.

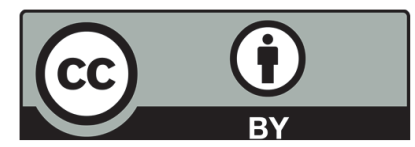

(C) 2018 by the authors; licensee Growing Science, Canada. This is an open access article distributed under the terms and conditions of the Creative Commons Attribution (CC-BY) license (http://creativecommons.org/licenses/by/4.0/). 